\title{
Using Polycyclic Aromatic Hydrocarbons (PAHs) as a chemical proxy to indicate Tsunami 2004 backwash in Khao Lak coastal area, Thailand
}

\author{
D. Tipmanee ${ }^{1,2}$, W. Deelaman ${ }^{3}$, S. Pongpiachan ${ }^{4}$, K. Schwarzer $^{5}$, and P. Sompongchaiyakul ${ }^{6}$ \\ ${ }^{1}$ International Postgraduate Program in Environmental Management, Graduate School, Chulalongkorn University, \\ Bangkok, Thailand \\ ${ }^{2}$ Center of Excellence for Environmental and Hazardous Waste Management (EHWM), Chulalongkorn University, \\ Bangkok, Thailand \\ ${ }^{3}$ Environmental Research and Training Center, Department of Environmental Quality Promotion, Ministry of Natural \\ Resources and Environment, Pathumthani, Thailand \\ ${ }^{4}$ The Graduate School of Social and Environmental Development, National Institute of Development Administration, \\ Bangkapi, Bangkok, Thailand \\ ${ }^{5}$ Institute of Geosciences, Coastal and Shelf Research, Kiel University, Otto-Hahn-Platz 1, 24118 Kiel, Germany \\ ${ }^{6}$ Department of Marine Science, Faculty of Science, Chulalongkorn University, Bangkok, Thailand
}

Correspondence to: P. Sompongchaiyakul (penjai.s@chula.ac.th)

Received: 29 December 2011 - Accepted: 7 February 2012 - Published: 14 May 2012

\begin{abstract}
In this study, we attempted to use PAHs as a chemical proxy to trace the transport of land-derived materials caused by the tsunami backwash to better understand how it may have affected the distribution of sedimentary deposition throughout the seabed of Khao Lak coastal areas. By analyzing the compositions of sedimentary PAHs in combination with application of the multivariate descriptive statistical techniques, PAHs were proven to be a promising chemical proxy to indicate the tsunami backwash in the study area. Their spatial distribution could indicate that the tsunami backwash plays an important role in transporting anthropogenic PAHs to the nearby coastal area as far as approximately $25 \mathrm{~km}$ from the shoreline. In addition, the results from diagnostic PAH isomer ratios suggested that road paving asphalt, originated from heavy erosion by the tsunami wave in front of Pakarang Cape, was among the identified sources of PAHs. Principle Component Analysis (PCA) results provided 2 estimated land-derived sources of PAHs, which were the road dust and oil burning sources. These estimated signature sources clearly support our hypothesis that PAHs were transported from the potential sources on land and deposited into the near-shore seabed during tsunami backwash.
\end{abstract}

\section{Introduction}

On 26 December 2004, the Indian Ocean tsunami attacked the Andaman coastal zones in Thailand, especially in the Phang Nga coastal area. The powerful nature of the 2004 tsunami resulted in extensive erosion and deposition of sediment throughout near-shore portions of the seabed in the Phang Nga coastal zones. The marine and terrestrial environments along the coastal zones were destroyed and caused widespread introduction of contaminated materials to the sea (Feldens et al., 2009; Tang et al., 2006; UNEP, 2005; Zhang et al., 2009). Therefore, in the area which was heavily affected by the withdrawal of the tsunami wave should contain more terrigenous sediments and thus relatively high proportions of anthropogenic derived sediment-associated contaminants.

A number of approaches have been used to distinguish between marine and terrigenous components in marine sediments, including polycyclic aromatic hydrocarbons (PAHs), hopanes and cholestanes (Mostafa et al., 2009; Takada et al., 1991; Tolosa et al., 2004; Yunker et al., 1995, 2002). However, PAHs are amongst the most promising sedimentassociated contaminants that can indicate the sedimentary deposition which was affected by tsunami backwash. This is due to the fact that they are known to enter aquatic environments through petroleum spills, coal and fossil fuels combustion, automobile exhausts, biomass burning and from non-point sources such as street runoff and atmospheric

Published by Copernicus Publications on behalf of the European Geosciences Union. 
fall-out (Ahrens and Depree, 2010; Jiang et al., 2009; Tolosa et al., 2009).

For decades, PAHs have been used as a "chemical proxy" to distinguish the anthropogenic source and biogenic source in marine sediment (Cantwell et al., 2007; Christensen et al., 1996; Fang et al., 2009; Tobiszewski and Namieśnik, 2012). They can be categorized as anthropogenic combustion sources (i.e. oil spill, automobile exhaust, and street runoff) and as natural combustion sources (i.e. forest fires, volcano eruption) by using PAHs diagnostic ratios (Yunker et al., 2002, 2011; Yunker and Macdonald, 2003). PAHs of molecular mass 178, 202 and 258 are commonly used to distinguish between pyrogenic (combustion-derived) and petrogenic (unburned petroleum-derived) sources. In addition, Phenanthrene/Anthracene $(\mathrm{m} / \mathrm{z}, 178)$, Fluorantene/Pyrene $(\mathrm{m} / \mathrm{z}, 202)$ and Benz[a]Anthracene/Chrysene $(\mathrm{m} / z, 258)$ have been previously used by some works (Khairy et al., 2009; Liu et al., 2009; Wang et al., 2006). Because of their usefulness in source identification, the use of PAHs as a chemical proxy may provide better understanding of huge terrigenous sediments caused by the rare events such as the withdrawal of tsunami waves.

Like many newly developed coastal tourist places, intensive economic-related activities, including the steadily increasing number of houses, hotels, restaurants, rapid urbanization along the coast, are major contributions for the significant accumulation of anthropogenic PAHs to the marine environment in the Khao Lak coastal area. Motor vehicle emissions, leakage of used oil, vehicle tire and asphalt road surfaces are typically diffuse sources of the anthropogenic PAHs in the coastal areas (Brown and Peake 2006; Kose et al., 2008).

During the tsunami backwash, severe damages occurred, including coastal shoreline erosion and destructive infrastructures such as buildings, road networks, bridges, fishing vessels, as well as the near-shore environment. As a consequence, the anthropogenic PAHs were believed to be transported from the potential sources on land and deposited into the near-shore seabed. Moreover, their spatial distribution should provide the extinctive patterns (concentration profile from shoreline to off-shore, compositions and concentrations of transporting PAHs) different from the normal transporting mechanisms such as those associated with the annual reversals of monsoons and hydro-meteorological extreme events or high precipitation in rainy season.

In this study, we attempt to use PAHs spatial distribution to trace the transport and fate of land-derived materials caused by the tsunami backwash to better understand how it may have affected the distribution of sedimentary deposition throughout the seabed in the Khao Lak coastal areas. In addition, the composition of the sedimentary PAHs of the Khao Lak coastal areas was analyzed using PAH diagnostic ratios in combination with the multivariate descriptive statistical techniques to distinguish among different sources of PAHs.

\section{Materials and methods}

\subsection{Study area and sampling methods}

Located on the east of the Andaman Sea, the near-shore of Kho Lak coastal zone, Phang Nga Province, Thailand was chosen as a study area, because it has heavily affected by the tsunami, which inundated the coastal plain from a few hundred meters up to more than one kilometer inland. The tsunami runup height at the maximum inundation limit varied from $<3 \mathrm{~m}$ on Kho Khao Island to almost $10 \mathrm{~m}$ at the Nham Kem and the Pakarang Cape (Szczuciñski, 2011). The tsunami wave height reached over $15 \mathrm{~m}$ at the Nham Kem (Tsuji et al., 2006) and the Pakarang Cape (Siripong, 2006). The sediment samples were collected in the study area covering approximately $750 \mathrm{~km}^{2}$ (east-west extension: $25 \mathrm{~km}$, north-south extension: $30 \mathrm{~km}$ ).

The sampling stations were selected on the basis of the data acquired from hydroacoustic mapping using equipment, which consisted of Multibeam, Side Scan Sonar and a Boomer system to investigate the sedimentary deposition on the near-shore seabed (Feldens, et al., 2009). Surface sediment samples were collected along the Khao Lak coastal area in order to analyze the distribution of 13 individual PAHs. The sampling stations are shown in Fig. 1.

The Van Veen Grab Sampler was used to collect the 70 surface sediment samples during 1-8 December 2007. Sediment samples were wrapped in clean aluminum foil, placed in a glass bottle, and kept frozen at $-20^{\circ} \mathrm{C}$. They were freezedried prior to being grounded and sieved to homogenize the samples, and then kept in the refrigerator at $-4^{\circ} \mathrm{C}$ until analysis.

\subsection{PAHs analysis}

All solvents were HPLC grade, purchased from Fisher Scientific. A mix standard solution of 15 native PAHs [Norwegian Standard (NS 9815: S-4008-100-T): phenanthrene (Abbreviation : Phe), anthracene (An), fluoranthene (Fluo), pyrene (Pyr), $11 \mathrm{H}$-benzo[a]fluorene $(11 \mathrm{H}-\mathrm{B}[\mathrm{a}] \mathrm{F})$, 11 H-benzo[b]fluorene (11H-B[b]F), benz[a]anthracene $(\mathrm{B}[\mathrm{a}] \mathrm{A})$, chrysene (Chry), benzo[b]fluoranthene $(\mathrm{B}[\mathrm{b}] \mathrm{F})$, benzo[k]fluoranthene $(\mathrm{B}[\mathrm{k}] \mathrm{F})$, benzo[a]pyrene $(\mathrm{B}[\mathrm{a}] \mathrm{P})$, benzo[e]pyrene $(\mathrm{B}[\mathrm{e}] \mathrm{P})$, indeno[1,2,3-cd]pyrene (Ind), dibenz[a,h]anthracene $(\mathrm{D}[\mathrm{a}, \mathrm{h}] \mathrm{A})$, and benzo[g,h,i]perylene $(\mathrm{B}[\mathrm{g}, \mathrm{h}, \mathrm{i}] \mathrm{P})]$ and a mix of recovery internal standard (IS) PAHs $\left[\mathrm{d}_{12}\right.$-perylene $\left(\mathrm{d}_{12}\right.$-Per $)$ and $\mathrm{d}_{10}$-fluorene $\left.\left(\mathrm{d}_{10}-\mathrm{Fl}\right)\right]$ were purchased from Chiron AS (Stiklestadveine 1, N7041 Trondheim, Norway). Standard stock solutions of deuterated and native PAHs were prepared in nonane. Working solutions were obtained by appropriate dilution in cyclohexane. 


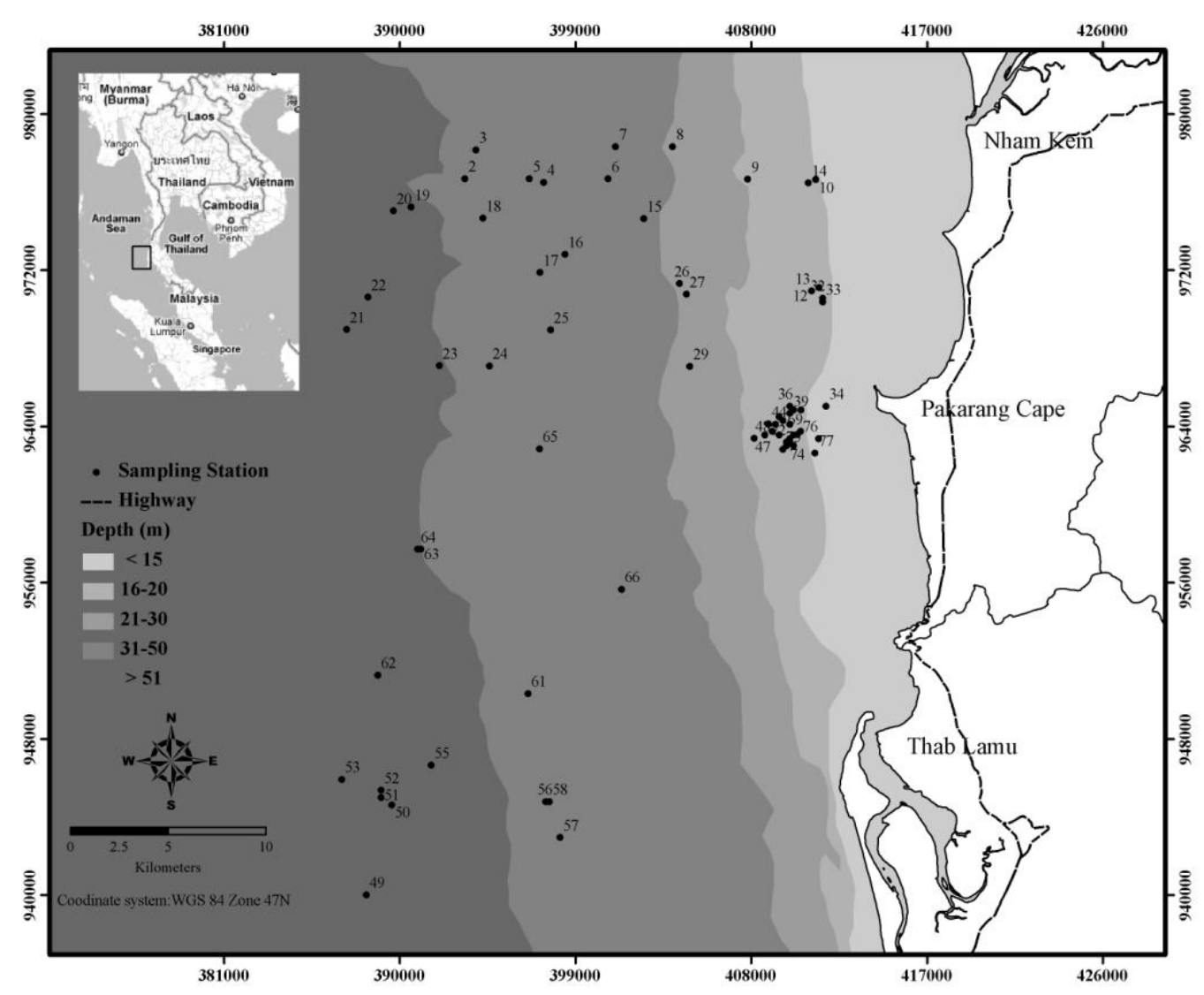

Fig. 1. Sampling site locations at Khao Lak coastal areas, Phang Nga Province, Thailand. (The study area is indicated by the black box; numbers indicate sampling stations; the color contours represent the water depth).

Approximately 5 grams of dried sediment were extracted by a Soxhlet extractor for $8 \mathrm{~h}$, using dichloromethane as a solvent. Before the extraction, dried sediments were spiked with a known amount of $\mathrm{d}_{10}$ - $\mathrm{Fl}$ and $\mathrm{d}_{12}$-Per as internal standards. Fractionation/clean-up process was carried out following the method of Gogou et al. (1997). The extractant was passed through a silica gel column using 4:6 (v/v) toluene:hexane as an eluant. The eluate was then purged with nitrogen to almost dryness. The solvent was then changed to cyclohexane and purged with nitrogen again until the final volume was $100 \mu \mathrm{l}$.

The aliquot solution was further quantified by using a Varian Saturn 2200 Gas Chromatography/Mass Spectrometric detector-Ion-Trap (GC/MS-Ion-Trap) in the selective ion monitoring mode. The targeted compounds were separated on an Agilent JW Scientific CP-5865 GC column $(60 \mathrm{~m} \times 0.32 \mathrm{~mm}$ i.d. capillary column, $1.00 \mu \mathrm{m}$ thick film). All injections $(1 \mu \mathrm{L})$ were performed through an injector in the splitless mode. The GC oven temperature was programmed as follows: $1 \mathrm{~min}$ at $40^{\circ} \mathrm{C}$, heated at $8^{\circ} \mathrm{C} \mathrm{min}^{-1}$ to $300^{\circ} \mathrm{C}$, and held constant for $45 \mathrm{~min}$. Accuracy was evaluated using the standard SRM 1941b. Mean recovery (based on extraction of matrix-matched certified reference materials, $(n=8)$ was in range of $77-119 \%$. The precision of the procedure, calculated as relative standard deviation on the duplicate samples, was less than $15 \%$. All sample concentrations were calculated using standardized relative response factors run with each batch.

\subsection{Statistical analysis}

Before performing statistical analysis, data were subjected to the logarithmic transformation $(\mathrm{y}=\log (\mathrm{x}+1))$. This technique is the most common approach for transforming environmental data, as it is robust to non-normal data distribution (Field et al., 1982). The significance level, KaiserMeyer-Olkin (KMO) and Bartlett's test of sphericity were performed to test the adaptability of Principal Component Analysis (PCA) (Wang et al., 2010). Data prepared for multivariate statistical analysis were arranged in the matrix, where columns correspond to PAH compositions and rows represent sampling stations. The normalized data matrix was then analyzed by PCA and Hierarchical Cluster Analysis (HCA).

PCA as a multivariate analytical tool was used to reduce the set of original observed variables (PAH compositions 


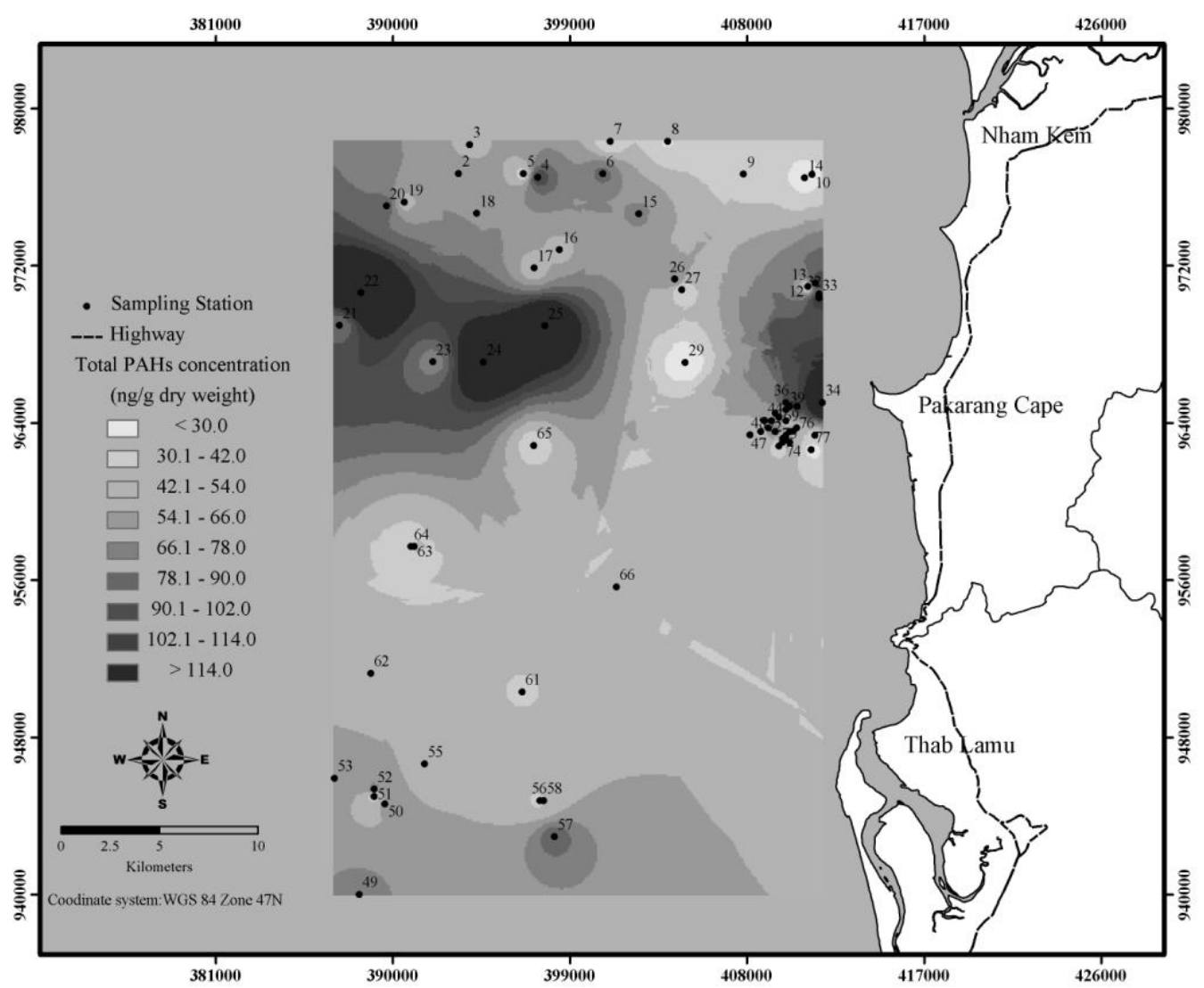

Fig. 2. The spatial distribution of sedimentary PAHs in the Khao Lak coastal area. (Numbers indicate sampling stations; the contour scale represents total PAHs concentrations as labeled in the legend).

Table 1. Comparisons of $\sum$ PAHs in surface sediment collected from different coastal areas and bays (ng g ${ }^{-1}$ dry weight).

\begin{tabular}{llll}
\hline Location & Range & Mean & Reference \\
\hline $\begin{array}{l}\text { Phang Nga Coast } \\
\text { Gulf of Thailand } \\
\text { Coastal areas }\end{array}$ & $12.6-272.0$ & 64.5 & $\begin{array}{l}\text { This study } \\
\text { Wattayakorn, 2005 } \\
\text { Offshore areas }\end{array}$ \\
$\begin{array}{llll}\text { Upper Gulf } \\
\text { Eastern Seaboard }\end{array}$ & $39-95$ & 506 & \\
Lower Gulf & $11-324$ & 79 & \\
Dalian Bay, China & $14-67$ & 51 & \\
Daya Bay, China & $32.7-3558$ & 152.08 & Liu et al., 2001 \\
Kyeonggi Bay, Korea & $42.5-158.2$ & 126.2 & Yan et al., 2009 \\
Malaysian riverine and coast & $9.1-1400$ & 120 & Kim et al., 1999 \\
Casco Bay, USA & $4-924$ & 139.5 & Zakaria et al., 2002 \\
Northwestern Black Sea & $16-20,748$ & 2900 & Kennicutt et al., 1999 \\
Todos Santos Bay, Mexico & $52.6-269$ & 136 & Maldonado et al., 1999 \\
Gulf of Aden, Yemen & $7.6-813$ & 96 & Macías-Zamora et al., 2000 \\
\hline
\end{tabular}


Table 2. Characteristic values of selected diagnostic ratios for petroleum and single-source combustion (Modified from Yunker et al., 2002).

\begin{tabular}{lcccc}
\hline Source & $\begin{array}{c}\text { An/ } \\
\text { (An+Phe) }\end{array}$ & $\begin{array}{c}\text { Flou/ } \\
\text { (Flou + Pyr) }\end{array}$ & $\begin{array}{c}\text { B [a]A/ } \\
\text { (B[a]A + Chry) }\end{array}$ & $\begin{array}{c}\text { Ind/ } \\
\text { (Ind + B[g,h,i]P) }\end{array}$ \\
\hline $\begin{array}{l}\text { Petroleum } \\
\text { Lubicating oil }\end{array}$ & - & 0.29 & 0.10 & 0.12 \\
Asphalt & - & - & 0.50 & $0.52-0.54$ \\
Combustion & & & & \\
Gasoline $(n=2)$ & 0.11 & 0.44 & $0.33-0.38$ & $0.09-0.22$ \\
Road dust & 0.18 & 0.42 & 0.13 & 0.51 \\
Used engine oil, gasoline passenger car & 0.22 & 0.30 & 0.50 & 0.18 \\
Used engine oil, diesel car, truck and bus & - & 0.37 & - & 0.29 \\
\hline
\end{tabular}

in sediment samples) and to extract a small number of the dominant principal components to explain the relationships among the observed variables (Larsen and Baker, 2003). To obtain more clear features, the Varimax rotation method with Kaiser normalization was used. In addition, HCA was used to group the stations by relative contents of PAH compounds in sediment samples. Distances of similarity between objects were measured as squared Euclidean distances (Fang et al., 2007). Ward's method was used for amalgamation of clusters (Savinov et al., 2000).

\section{Results and discussion}

\subsection{PAHs contamination in Khao Lak coastal area}

On the basis of sediment analysis, the total concentration of PAHs ( $\sum$ PAHs) is defined as the sum of Phe, An, Fluo, Pyr, B[a]A, Chry, B[b]F, B[k]F, B[e]P, B[a]P, Ind, D[a,h]A, and $B[g, h, i] P$. $\sum$ PAHs in the Khao Lak area, which was heavily destroyed by the tsunami runup, were in range of 12.6 to $272.0 \mathrm{ng} \mathrm{g}^{-1}$ dry weight, with an average of $64.5 \pm$ $44.3 \mathrm{ng} \mathrm{g}^{-1}$ dry weight. It should be noted that the PAHs concentrations detected in the Khao Lak coastal sediments are comparable with those contaminations found previously in some coastal areas and bays (Table 1). However, they were much lower than some coastal and harbor hot spots that are highly under an influence of human activities such as Dalian Bay, Casco Bay and Kyeonggi Bay (Table 1).

Figure 2 shows the spatial distributions of sedimentary PAHs in the Khao Lak coastal area. From the figure, the prominent feature of sediments exported from the Pakarang Cape can be observed. This evidence indicates that the tsunami backwash may play an important role in transporting anthropogenic PAHs to the nearby coastal area far from the shoreline up to approximately $25 \mathrm{~km}$. It is also in good agreement with the study of Siripong (2006), who found that the tsunami wave height was over $15 \mathrm{~m}$ high at Pakarang Cape. Such a giant wave could have a tremendous impact on transporting massive terrigenous sediments far from the shoreline, as evidenced from the distinct spatial patterns of PAHs concentrations (Fig. 2).

Generally, PAH concentrations should gradually decrease offshore further along the distance far from the point source that has original concentration (Boonyatumanond et al., 2006). But the PAH concentrations from sediments exported from the Pakarang Cape increased further along the distance up to 25 kilometers. These behaviors are triggered by a rare event such as the tsunami backwash not originating from normal transporting mechanisms such as those associated with the annual reversals of monsoon and hydro-meteorological extreme events or high precipitation in rainy season.

\subsection{Source identification by diagnostic PAH isomer ratios}

The characteristics of PAH patterns in the coastal sediments are subject to different emission sources. Thus, isomer ratios of PAHs have been used to identify PAH sources, ranging from urban to marine environments (Yunker et al., 2002). Pyrogenic and petrogenic are the primary sources of PAHs commonly found in coastal marine sediments (LaFlamme and Hites, 1978).

The four PAH isomer pairs used in the present study were An/(An + Phe) $(m / z$ 178), Flou/(Flou + Pyr) (MW 202), $\mathrm{B}$ [a]A /(B[a]A + Chry) $(m / z 228)$, and Ind/(Ind + B [g,h,i]P) $(\mathrm{m} / \mathrm{z}$ 276). Table 2 shows ranges of the 4 diagnostic $\mathrm{PAH}$ ratios for petroleum and single-source combustion.

Cross-plots between ratios $\mathrm{B}[\mathrm{a}] \mathrm{A} /(\mathrm{B}[\mathrm{a}] \mathrm{A}+\mathrm{Chry})$ and Ind/(Ind $+\mathrm{B}[\mathrm{g}, \mathrm{h}, \mathrm{i}] \mathrm{P})$ were applied to identify the potential sources of sedimentary PAHs in study area. The results indicated that most of sediment samples originated from the mixed pyrogenic sources as results of the incomplete combustion, pyrolysis of fuel, biomass burning and oil burning.

On the basis of the results shown in Table 2, the $\mathrm{B}[\mathrm{a}] \mathrm{A} /(\mathrm{B}[\mathrm{a}] \mathrm{A}+\mathrm{Chry})$ and $\mathrm{Ind} /(\operatorname{Ind}+\mathrm{B}[\mathrm{g}, \mathrm{h}, \mathrm{i}] \mathrm{P})$ ratios were 0.50 and $0.52-0.54$, respectively, indicating the plausible emission source from asphalt pavements. Moreover, Yang et al. (2010) reported that even minimal contamination of sediments with pavement material may lead to a significant input 


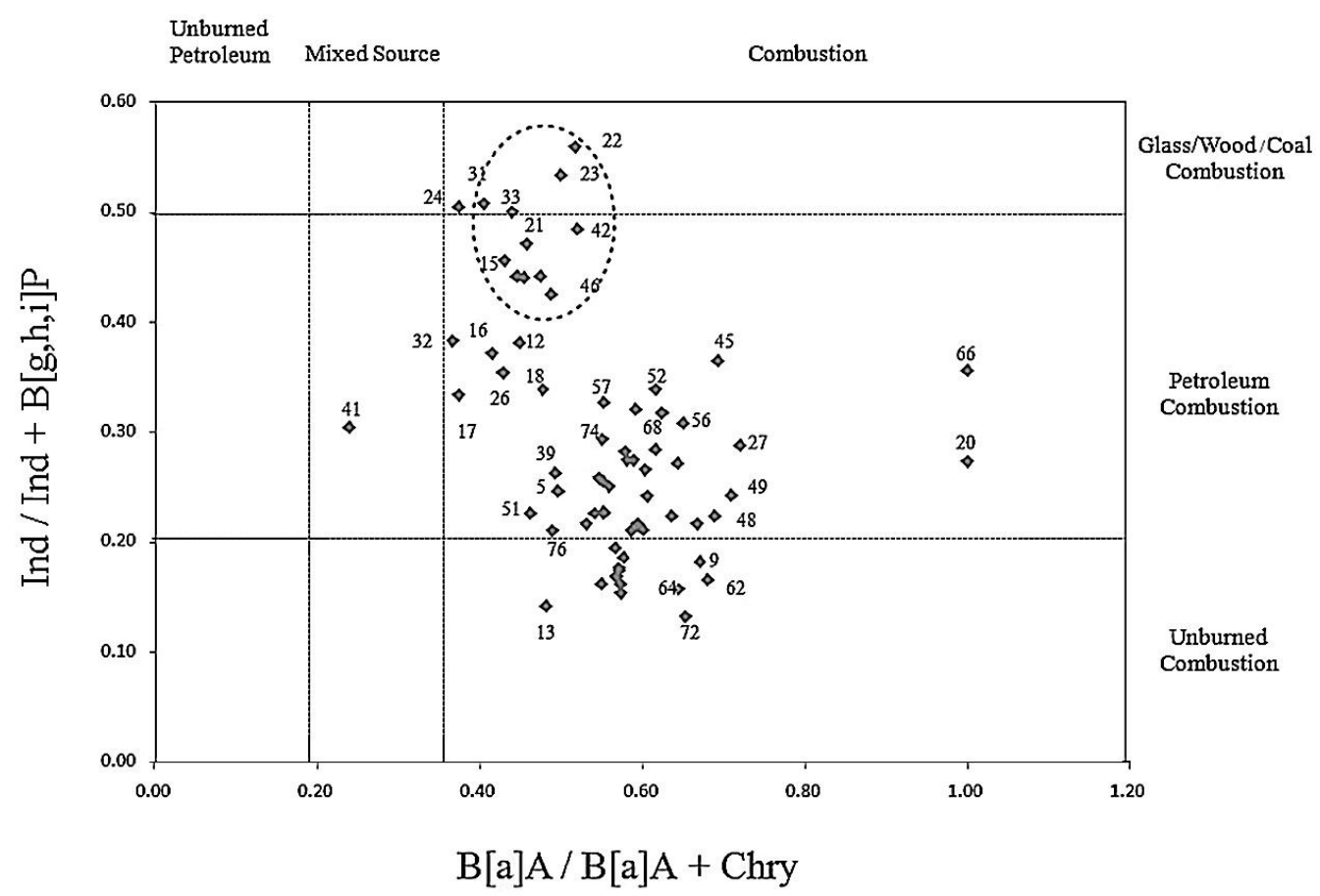

Fig. 3. Cross-plot between ratios Ind/Ind+B[g,h,i]P and $\mathrm{B}[\mathrm{a}] \mathrm{A} / \mathrm{B}[\mathrm{a}] \mathrm{A}+\mathrm{Chry}$ (numbers indicate sampling stations; the dashed circle represents the stations in which PAHs were originating from road paving asphalt).

of PAHs to the aquatic environment. This agreed with our results that hot spot stations (22, 25, 31, 33 and 42 in Fig. 2) showed the higher concentration of total PAHs. The signature diagnostic PAHs isomer ratios, which indicated to road paving asphalt were observed in the stations 22, 25, 31, 33 and 42 (The dashed circle in Fig. 3). We believe that the promising PAH sources of these stations originated from the road paving asphalt heavily eroded by the tsunami wave in front of Pakarang Cape.

Pomonis et al. (2005) reported that the damage to the road surface was observed in the areas near the Khao Lak coastline. This damage was probably due to increased pore water pressure under the flexible pavement. This evidence was visible on small areas of road surface adjacent to the beach front and especially on grasscrete surfaces (e.g. at Kamala and Pakarang Cape).

From the results derived from the diagnostic PAH isomer ratios, it meets our attempted goal to use PAHs as a chemical proxy to trace the transport of land-derived materials caused by the tsunami backwash. The diagnostic PAH isomer ratios provide clear evidence that the anthropogenic PAHs were transported from the coastal land and deposited into the nearshore seabed during the tsunami backwash.

Nevertheless, it is important to note that isomer pair ratios of the entire dataset were not restricted to the extreme values of only specific source, because there is a chance to misinterpret when the mixtures of heterogeneous PAH sources are

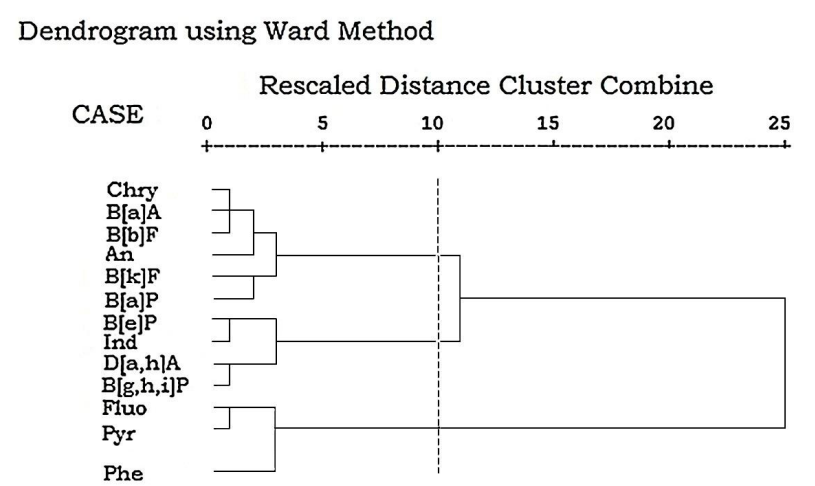

Fig. 4. Hierarchical Cluster Analysis (HCA) of 13 individual PAHs in Khao Lak sediment.

analyzed, especially in the case of the powerful and strongly turbulent tsunami wave that can transport the PAH contaminated materials to the sea floor all at once (Tang et al., 2006).

\subsection{Source estimation from HCA}

HCA was performed to identify the homogeneous groups of individual PAHs in the Khao Lak sediment. The hierarchical dendogram is shown in Fig. 4. What emerged from these results is that three major groups of the 13 individual PAHs were clearly distinguished. The first group contains B[a]A, 


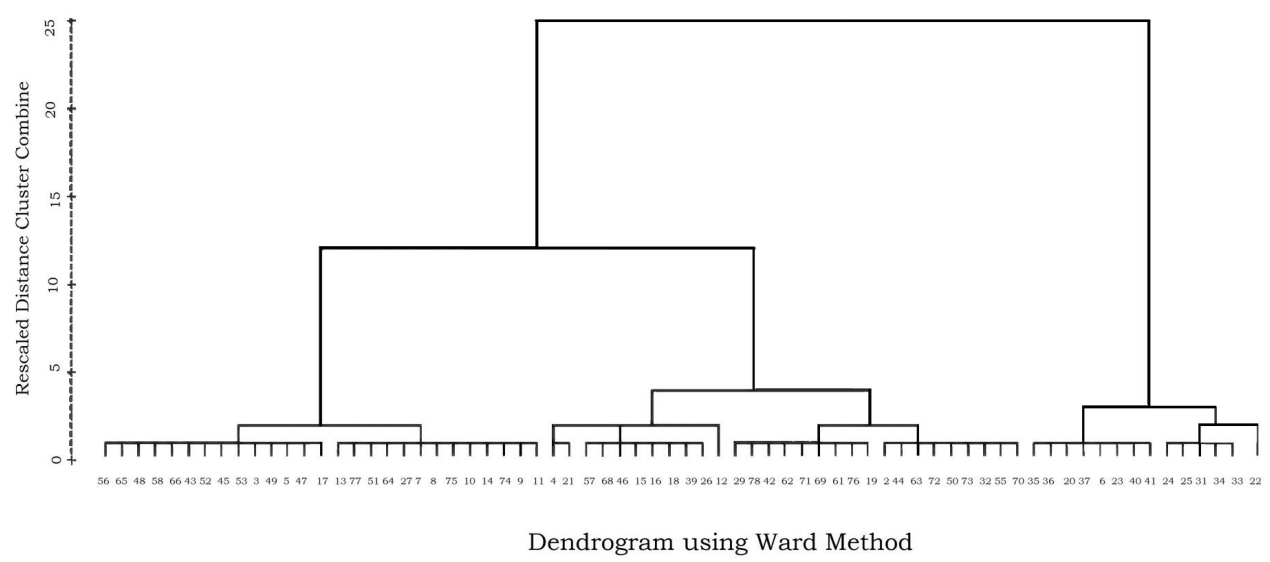

Fig. 5. Hierarchical Cluster Analysis (HCA) of 70 individual sampling stations in Khao Lak sediment.

Chry, B[b]F, B $[\mathrm{k}] \mathrm{F}, \mathrm{B}[\mathrm{a}] \mathrm{P}$ and An, which originated from the pyrogenic source (Fang et al., 2009; Liu et al., 2009). Motor vehicle emissions both of gasoline and diesel emission, leakage of used oil and road dust have been previously identified as original sources of this group (Dahle et al., 2003). According to the literature reports, the 3-4 ring PAHs have been found in the road dust in urban cities as well (Boonyatumanond et al., 2007; Zakaria et al., 2002).

The second group consists of $\mathrm{B}[\mathrm{e}] \mathrm{P}$, Ind, $\mathrm{D}[\mathrm{a}, \mathrm{h}] \mathrm{A}$ and $\mathrm{B}[\mathrm{g}, \mathrm{h}, \mathrm{i}] \mathrm{P}$, which are the high molecular weight PAHs with 5-6rings. This group usually originated from road paving asphalt, crude oil, bitumen (Ahrens and Depree, 2010) and road dust (Larsen and Baker, 2003). The last group comprises Pyr, Fluo and Phe, which are the anthropogenic PAHs from the using of petroleum products (Zhou et al., 1999).

It is reasonable to say that three of the potential sources which were identified by HCA could be transported from original sources during the tsunami backwash as we expected. Moreover, the results based on the cluster analysis by the 70 individual sampling stations revealed two major groups as shown in Fig. 5.

The first group includes stations 6, 20, 22, 23, 24, 25, 31, $33,34,35,36,37,40$ and 41 . All of these stations have distinct characteristics from other areas, consistent with what is documented in Fig. 2. Thus, this group should be the representative of the tsunami backwash and so results can provide the approximate direction of the tsunami backwash that was transported from the shoreline at Pakarang Cape back to far further than $25 \mathrm{~km}$ into the seabed. In contrast, the second group includes the rest of sampling stations. The nearby group which has less linkage distance between homogeneous groups (more similarity), contains stations 2, 32, 44, 50, 55, $63,70,72$ and 73 , and also indicates the influence of the tsunami backwash.
Table 3. Rotated component matrix of 13 PAHs from Khao Lak coastal sediments ${ }^{\mathrm{a}}$.

\begin{tabular}{lll}
\hline \multirow{2}{*}{ PAH composition } & \multicolumn{2}{l}{ Principle components (PC) } \\
\cline { 2 - 3 } & PC1 & PC 2 \\
\hline Phe & 0.02 & 0.58 \\
An & 0.08 & 0.53 \\
Fluo & 0.12 & $\mathbf{0 . 8 8}$ \\
Pyr & 0.04 & $\mathbf{0 . 8 6}$ \\
B[a]A & 0.15 & 0.54 \\
Chry & 0.24 & 0.48 \\
B[b]F & 0.47 & 0.22 \\
B[k]F & $\mathbf{0 . 7 5}$ & 0.18 \\
B[e]P & $\mathbf{0 . 8 9}$ & 0.19 \\
B[a]P & 0.60 & 0.42 \\
Ind & $\mathbf{0 . 9 1}$ & 0.03 \\
D[a,h]A & $\mathbf{0 . 9 3}$ & 0.17 \\
B[g,h,i]P & $\mathbf{0 . 9 2}$ & -0.10 \\
Estimated source & Road dust & Oil burning \\
Variance (\%) & $\mathbf{6 1 . 4}$ & $\mathbf{1 1 . 6}$ \\
\hline
\end{tabular}

a Rotation Method: Varimax with Kaiser normalization

$\mathrm{b}$ Bold loading $>0.70$

\subsection{Source identification by PCA}

In this study, concentrations of 13 PAHs and the 70 samples were selected as active variables and subjects, respectively. The majority of the variance $(73.0 \%)$ of the scaled data was explained by two eigenvectors-principal components. The first principal component (PC1) can explain $61.4 \%$ of the total variance, and the second (PC2) can explain $11.6 \%$ of the total variance, respectively, as shown in Table 3.

The $\mathrm{PC} 1$ is heavily weighted in $\mathrm{B}[\mathrm{b}] \mathrm{F}, \mathrm{B}[\mathrm{e}] \mathrm{P}$, Ind, $\mathrm{D}[\mathrm{a}, \mathrm{h}] \mathrm{A}$ and $\mathrm{B}[\mathrm{g}, \mathrm{h}, \mathrm{i}] \mathrm{P}$, which are the high molecular weight PAHs with 5-6 rings. This group usually originates from road 
Table A4. Accuracy test withSRM $1941 b$.

\begin{tabular}{lccccc}
\hline SRM & Abbr & $n$ & $\begin{array}{c}\text { Reference Valve } \\
\text { ng g-1 } \\
\text { dry weight }\end{array}$ & $\begin{array}{c}\text { Measuring Valve } \\
\text { ng g-1 } \\
\text { dry weight }\end{array}$ & \% Accuracy \\
\hline Phenanthrene & Phe & 8 & $406 \pm 44$ & $486 \pm 66$ & $120 \pm 16$ \\
Fluoranthene & Fluo & 8 & $651 \pm 50$ & $733 \pm 79$ & $113 \pm 12$ \\
Pyrene & Pyr & 8 & $581 \pm 39$ & $551 \pm 65$ & $95 \pm 11$ \\
Benzo[a]anthracene & B[a]A & 8 & $335 \pm 25$ & $277 \pm 46$ & $83 \pm 13$ \\
Chrysene & Chry & 8 & $291 \pm 31$ & $227 \pm 83$ & $78 \pm 28$ \\
Benzo[b]fluoranthene & B[b]F & 8 & $453 \pm 21$ & $396 \pm 134$ & $87 \pm 29$ \\
Benzo[k]fluoranthene & B[k]F & 8 & $225 \pm 18$ & $197 \pm 86$ & $88 \pm 38$ \\
Benzo[e]pyrene & B[e]P & 8 & $325 \pm 25$ & $409 \pm 175$ & $126 \pm 53$ \\
Indeno[1,2,3-cd]pyrene & Ind & 8 & $341 \pm 57$ & $438 \pm 92$ & $129 \pm 26$ \\
Benzo[g,h,i]perylene & B [g,h,i]P & 8 & $307 \pm 45$ & $382 \pm 84$ & $124 \pm 27$ \\
\hline
\end{tabular}

Table A5. Five of Diagnostic ratios of Khao Lak sediments.

\begin{tabular}{|c|c|c|c|c|c|}
\hline Station & $\mathrm{An} / \mathrm{An}+\mathrm{Phe}$ & Flou/Flou + Pyr & B [a]A/B[a]A + Chry & $\mathrm{B}[\mathrm{a}] \mathrm{P} / \mathrm{B}[\mathrm{a}] \mathrm{P}+\mathrm{B}[\mathrm{e}] \mathrm{P}$ & Ind/Ind $+\mathrm{B}[\mathrm{g}, \mathrm{h}, \mathrm{i}] \mathrm{P}$ \\
\hline 2 & 0.25 & 0.35 & 0.49 & - & 0.21 \\
\hline 3 & 0.33 & 0.35 & 0.59 & 0.38 & 0.21 \\
\hline 4 & 0.09 & 0.49 & 0.43 & 0.39 & 0.46 \\
\hline 5 & 0.13 & 0.44 & 0.50 & 0.33 & 0.25 \\
\hline 6 & 0.34 & 0.24 & 0.64 & 0.42 & 0.27 \\
\hline 7 & 0.40 & 0.30 & 0.60 & - & 0.21 \\
\hline 8 & 0.33 & 0.33 & 0.61 & 0.50 & 0.24 \\
\hline 9 & 0.54 & 0.51 & 0.67 & - & 0.18 \\
\hline 10 & 0.09 & 0.67 & 0.57 & 0.28 & 0.15 \\
\hline 11 & 0.53 & 0.39 & 0.55 & - & 0.23 \\
\hline 12 & 0.54 & 0.51 & 0.45 & 0.38 & 0.38 \\
\hline 13 & 0.38 & 0.43 & 0.48 & 0.08 & 0.14 \\
\hline 14 & 0.56 & 0.29 & 0.56 & - & 0.25 \\
\hline 15 & 0.33 & 0.39 & 0.45 & 0.06 & 0.44 \\
\hline 16 & 0.46 & 0.41 & 0.41 & - & 0.37 \\
\hline 17 & 0.28 & 0.48 & 0.37 & 0.08 & 0.33 \\
\hline 18 & 0.26 & 0.42 & 0.48 & - & 0.34 \\
\hline 19 & 0.14 & 0.31 & 0.59 & 1.00 & - \\
\hline 20 & 0.26 & 0.27 & 1.00 & - & 0.27 \\
\hline 21 & 0.10 & 0.32 & 0.46 & 0.45 & 0.47 \\
\hline 22 & 0.39 & 0.32 & 0.52 & - & 0.56 \\
\hline 23 & 0.47 & 0.29 & 0.50 & 0.34 & 0.53 \\
\hline 24 & 0.13 & 0.52 & 0.37 & 0.42 & 0.50 \\
\hline 25 & 0.14 & 0.44 & 0.45 & 0.38 & 0.44 \\
\hline 26 & 0.58 & 0.28 & 0.43 & 0.34 & 0.35 \\
\hline 27 & 0.23 & 0.15 & 0.72 & - & 0.29 \\
\hline 29 & 0.15 & 0.25 & 0.64 & 0.04 & 0.22 \\
\hline 31 & 0.09 & 0.48 & 0.40 & 0.29 & 0.51 \\
\hline 32 & 0.33 & 0.32 & 0.37 & - & 0.38 \\
\hline 33 & 0.16 & 0.47 & 0.44 & - & 0.50 \\
\hline 34 & 0.12 & 0.48 & 0.54 & 0.56 & 0.23 \\
\hline 35 & 0.17 & 0.37 & 0.55 & 0.18 & 0.26 \\
\hline 36 & 0.23 & 0.30 & 0.55 & - & 0.25 \\
\hline 37 & 0.16 & 0.30 & 0.53 & 0.30 & 0.01 \\
\hline 39 & 0.19 & 0.40 & 0.49 & 0.03 & 0.26 \\
\hline
\end{tabular}


Table A6. Five of Diagnostic ratios of Khao Lak sediments (continued).

\begin{tabular}{|c|c|c|c|c|c|}
\hline Station & $\mathrm{An} / \mathrm{An}+\mathrm{Phe}$ & Flou/Flou + Pyr & $\mathrm{B}[\mathrm{a}] \mathrm{A} / \mathrm{B}[\mathrm{a}] \mathrm{A}+$ Chry & $\mathrm{B}[\mathrm{a}] \mathrm{P} / \mathrm{B}[\mathrm{a}] \mathrm{P}+\mathrm{B}[\mathrm{e}] \mathrm{P}$ & Ind/Ind + B[g,h,i]P \\
\hline 40 & 0.32 & 0.29 & 0.47 & 0.42 & 0.44 \\
\hline 41 & 0.38 & 0.32 & 0.24 & 0.52 & 0.30 \\
\hline 42 & 0.18 & 0.34 & 0.52 & - & 0.48 \\
\hline 43 & 0.08 & 0.42 & 0.51 & 0.06 & - \\
\hline 44 & 0.36 & 0.45 & 0.57 & - & 0.19 \\
\hline 45 & 0.31 & 0.30 & 0.69 & 0.13 & 0.36 \\
\hline 46 & 0.08 & 0.30 & 0.49 & 0.34 & 0.43 \\
\hline 47 & 0.21 & 0.31 & 0.55 & - & 0.23 \\
\hline 48 & 0.22 & 0.26 & 0.69 & 0.49 & 0.22 \\
\hline 49 & 0.36 & 0.32 & 0.71 & 0.05 & 0.24 \\
\hline 50 & 0.21 & 0.44 & 0.59 & - & 0.27 \\
\hline 51 & 0.36 & 0.35 & 0.46 & 0.50 & 0.23 \\
\hline 52 & 0.10 & 0.31 & 0.62 & 0.08 & 0.34 \\
\hline 53 & 0.26 & 0.35 & 0.63 & - & 0.32 \\
\hline 55 & 0.33 & 0.29 & 0.62 & 0.01 & 0.28 \\
\hline 56 & 0.21 & 0.31 & 0.65 & - & 0.31 \\
\hline 58 & 0.22 & 0.32 & 0.60 & 0.34 & 0.27 \\
\hline 57 & 0.41 & 0.19 & 0.55 & 0.38 & 0.33 \\
\hline 61 & 0.29 & 0.29 & 0.58 & 0.38 & 0.27 \\
\hline 62 & 0.31 & 0.29 & 0.68 & 0.05 & 0.17 \\
\hline 63 & 0.34 & 0.29 & 0.53 & - & 0.22 \\
\hline 64 & 0.25 & 0.38 & 0.65 & 0.07 & 0.16 \\
\hline 65 & 0.26 & 0.34 & 0.58 & - & 0.28 \\
\hline 66 & 0.16 & 0.26 & 1.00 & 0.21 & 0.36 \\
\hline 68 & 0.26 & 0.20 & 0.59 & 0.47 & 0.32 \\
\hline 69 & 0.24 & 0.27 & 0.57 & 0.05 & 0.17 \\
\hline 70 & 0.20 & 0.28 & 0.58 & - & 0.19 \\
\hline 71 & 0.24 & 0.30 & 0.57 & 0.05 & 0.18 \\
\hline 72 & 0.23 & 0.31 & 0.57 & 0.23 & 0.16 \\
\hline 73 & 0.15 & 0.53 & 0.65 & 0.02 & 0.13 \\
\hline 74 & 0.24 & 0.39 & 0.55 & - & 0.29 \\
\hline 75 & 0.21 & 0.33 & 0.57 & 0.42 & 0.17 \\
\hline 76 & 0.20 & 0.31 & 0.55 & - & 0.16 \\
\hline 77 & 0.48 & 0.33 & 0.67 & 0.10 & 0.22 \\
\hline 78 & 0.44 & 0.35 & 0.59 & - & 0.22 \\
\hline
\end{tabular}

paving asphalt, crude oil, bitumen and road dust. Therefore, the PC1 is a representative of the road dust sources of PAHs. In contrast, the PC2 is predominately composed of Pyr and Fluo. This group usually originates from the use of petroleum product and oil combustion. Fang et al. (2006) reported that high loadings of Pyr and Fluo indicated incomplete combustion, pyrolysis of fuel and oil burning. This factor is believed to be the oil burning source of PAHs.

Since a tsunami wave can have tremendous impacts on transporting a large amount of terrigenous sediments to the sea, the mixtures of heterogeneous PAH sources are needed to take into account source identification. Even though the PCA results are similar to those of the HCA, the estimated sources from the PCA can reduce the estimated sources from three (HCA) to two sources. Thus, the PCA makes it easier to interpret the estimated sources.
A significant correlation identified by PCA, which indicates 2 estimated sources of the PAHs signatures, clearly supports our hypothesis that PAHs were transported from the potential sources on land and deposited into the near-shore seabed during tsunami backwash.

\section{Conclusions}

By analyzing the compositions of sedimentary PAHs in combination with application of the multivariate descriptive statistical techniques, PAHs were proven to be a promising chemical proxy to indicate the tsunami backwash, which have affected the near-shore portions of the seabed in the Khao Lak coastal zones.

The PAHs spatial distribution could indicate the distance at which the land-derived materials were transported offshore 
as a result of the tsunami backwash. The prominent feature of surface sediments exported from the Pakarang Cape could be observed. This evidence indicates that the tsunami backwash plays an important role in transporting anthropogenic PAHs to the nearby coastal area as far as approximately 25 kilometers from the shoreline. In addition, the results from diagnostic PAH isomer ratios suggested that road paving asphalt, originating from heavy erosion by the tsunami wave in front of Pakarang Cape, was among the identified sources of PAHs.

Moreover, PCA results provided 2 estimated land-derived sources of PAHs, which were the road dust and oil burning sources. These estimated signature sources clearly support our hypothesis that PAHs were transported from the potential sources on land and deposited into the near-shore seabed during tsunami backwash. However, the temporal distribution is needed to validate our innovative study in further work.

Acknowledgements. The study was financially supported by the ThaiGerman Research Cooperation (NRCT-DFG), under the project Tracing Tsunami Impacts on and offshore in the Andaman Sea Region, TRIAS, Center of Excellence for Environmental and Hazardous Waste Management (CE-EHWM) and the 90th Anniversary of Chulalongkorn University Fund (Ratchadaphiseksomphot Endowment Fund). The authors would like to thank the Phuket Marine Biological Center (PMBC) for providing us with RV CHAKRATONG TONGYAI and to Department of Marine Science, Faculty of Science, Chulalongkorn University for providing facility in this study. The authors also gratefully acknowledge the constructive comments and corrections on the manuscript by A. Limsakul. The authors gratefully acknowledge the anonymous reviewers for their valuable comments and suggestions that greatly improved this work.

Edited by: H. Sterr

Reviewed by: three anonymous referees

\section{References}

Ahrens, M. J. and Depree, C. V.: A source mixing model to apportion PAHs from coal tar and asphalt binders in street pavements and urban aquatic sediments, Chemosphere, 81, 15261535, 2010.

Boonyatumanond, R., Wattayakorn, G., Togo, A., and Takada, H.: Distribution and origins of polycyclic aromatic hydrocarbons (PAHs) in riverine, estuarine, and marine sediments in Thailand, Mar. Pollut. Bull., 52, 942-956, 2006.

Boonyatumanond, R., Wattayakorn, G., Amano, A., Inouchi, Y., and Takada, H.: Reconstruction of pollution history of organic contaminants in the upper Gulf of Thailand by using sediment cores: First report from Tropical Asia Core (TACO) project, Mar. Pollut. Bull., 54, 554-565, 2007.

Brown, J. N. and Peake, B. M.: Sources of heavy metals and polycyclic aromatic hydrocarbons in urban stormwater runoff, Sci. Total. Environ., 359, 145-155, 2006.

Cantwell, M. G., King, J. W., Burgess, R. M., and Appleby, P. G.: Reconstruction of contaminant trends in a salt wedge estu- ary with sediment cores dated using a multiple proxy approach, Mar. Environ. Res., 64, 225-246, 2007.

Christensen, E. R. and Karls, J. F.: Unmixing of lead, ${ }^{137}$ Cs, and PAH records in lake sediments using curve fitting with first- and second-order corrections, Water. Res., 30, 2543-2558, 1996.

Dahle, S., Savinov, V. M., Matishov, G. G., Evenset, A., and Nas, K.: Polycyclic aromatic hydrocarbons (PAHs) in bottom sediments of the Kara Sea shelf, Gulf of Ob and Yenisei Bay, Sci. Total. Environ., 306, 57-71, 2003.

Fang, G. C., Wu, Y. S., Chen, J. C., Chang, C. N., and Ho, T. T.: Characteristic of polycyclic aromatic hydrocarbon concentrations and source identification for fine and coarse particulates at Taichung Harbor near Taiwan Strait during 2004-2005, Sci. Total. Environ., 366, 729-738, 2006.

Fang, M. D., Hsieh, P. C., Ko, F. C., Baker, J. E., and Lee, C. L.: Sources and distribution of polycyclic aromatic hydrocarbons in the sediments of Kaoping river and submarine canyon system, Taiwan, Mar. Pollut. Bull., 54, 1179-1189, 2007.

Fang, M. D., Chang, W. K., Lee, C. L., and Liu, J. T.: The use of polycyclic aromatic hydrocarbons as a particulate tracer in the water column of Gaoping (Kaoping) Submarine Canyon, J. Mar. Syst., 76, 457-467, 2009.

Feldens, P., Schwarzer, K., Szczuciñski, W., Stattegger, K., Sakuna, D., and Somgpongchaiykul, P.: Impact of the 2004 Indian Ocean Tsunami on Seafloor Morphology and Sediments Offshore Pakarang Cape, Thailand, Pol. J. Environ. Stud., 18, 6368, 2009.

Field, J. G., Clarke, K. R., and Warwick, R. M.: A practical strategy for analysing multispecies distribution patterns, Mar. Ecol. Prog. Ser., 8, 37-52, 1982.

Gogou, A. I., Apostolaki, M., and Stephanou, G. E.: Determination of organic molecular markers in marine aerosols and sediments: one-step flash chromatography compound class fractionation and capillary gas chromatographic analysis, J. Chromatogr. A., 799, 215-231, 1997.

Jiang, J. J., Lee, C. L., Fang, M. D., and Liu, J. T.: Polycyclic aromatic hydrocarbons in coastal sediments of southwest Taiwan: An appraisal of diagnostic ratios in source recognition, Mar. Pollut. Bull., 58, 752-760, 2009.

Kim, G. B., Maruya, K. A., Lee, R. F., Lee, J. H., Koh, C. H., and Tanabe, S.: Distribution and sources of polycyclic aromatic hydrocarbons in sediments from Kyeonggi Bay, Korea, Mar. Pollut. Bull., 38, 7-15, 1999.

Kennicutt, II M. C., Wade, T. L., Presley, B. J., Requejo, A. G., Brooks, J. M., and Denoux, G. J.: Sediment contaminants in Casco Bay, Maine: inventories, sources, and potential for biological impact, Environ. Sci. Technol., 28, 1-15, 1999.

Kose, T., Yamamoto, T., Anegawa, A., Mohri, S., and Ono, Y.: Source Analysis for Polycyclic Aromatic Hydrocarbon in Road Dust and Urban Runoff Using Marker Compounds, Desalination, 226, 151-159, 2008.

Khairy, M. A., Kolb, M., Mostafa, A. R., EL-Fiky, A., and Bahadir, M.: Risk assessment of polycyclic aromatic hydrocarbons in a Mediterranean semi-enclosed basin affected by human activities (Abu Qir Bay, Egypt), J. Hazard. Mater., 170, 389-397, 2009.

LaFlamme, R. E. and Hites, R. A.: The global distribution of polycyclic aromatic Hydrocarbons in recent sediments, Geochim. Cosmochim. Ac., 42, 289-303, 1978.

Larsen, R. K. and Baker, J. E.: Source apportionment of polycyclic 
aromatic hydrocarbons in the urban atmosphere: a comparison of three methods, Environ. Sci. Technol., 37, 1873-81, 2003.

Liu, X. M., Xu, X. R., Zhang, X. T., Zhou, C. G., and Li, H. A.: Preliminary study on PAHs in the surface sediment samples from Dalian Bay, Acta. Scien. Circum., 21, 507-509, 2001.

Liu, Y., Chena, L., Huang, Q. H., Li, W. Y., Tang, Y. J., and Zhao, J. F.: Source apportionment of polycyclic aromatic hydrocarbons (PAHs) in surface sediments of the Huangpu River, Shanghai, China, Sci. Total. Environ., 407, 2931-2938, 2009.

Macías-Zamora, J. V., Mendoza-Vega, E., and Villaescusa-Celaya, J. A.: PAHs composition of surface marine sediments: a comparison to potential local sources in Todos Santos Bay, BC, Mexico, Chemosphere, 46, 459-468, 2002.

Maldonado, C., Bayona, J. M., and Bodineau, L.: Sources, distribution, and water column processes of aliphatic and polycyclic aromatic hydrocarbons in the Northwestern Black Sea Water, Environ. Sci. Technol., 33, 2693-2702, 1999.

Mostafa, A. R., Wade, T. L., Sweet, S. T., Al-Alimi, A. A., and Barakat, A. O.: Distribution and characteristics of polycyclic aromatic hydrocarbons (PAHs) in sediments of Hadhramout coastal area, Gulf of Aden, Yemen, J. Marine. Syst., 78, 1-8, 2009

Pomonis, A., Rossetto, T., Wilkinson, S. M., Del Re, D., Peiris, N., Koo, R., Manlapig, R., and Gallocher, S.: The Indian Ocean Tsunami 26th December 2004. Earthquake Field Investigation TeamReport, Institution of Structural Engineers, UK, 180 pp., 2005.

Savinov, V. M., Savinova, T. N., Carroll, J., Matishova, G. G., Dahle, S., and Naes, K.: Polycyclic Aromatic Hydrocarbons (PAHs) in Sediments of the White Sea, Russia, Mar. Pollut. Bull., 40, 807-818, 2000.

Siripong, A.: Andaman seacoast of Thailand field survey after the December 2004 Indian Ocean tsunami, Earthq. Spectra., 22, 187-202, 2006.

Szczuciñski, W.: The post-depositional changes of the onshore 2004 tsunami deposits on the Andaman Sea coast of Thailand, doi:10.1007/s11069-011-9956-8, 2011.

Takada, H., Onda, T., Harada, M., and Ogura, N.: Distribution and Sources of Polycyclic Aromatic Hydrocarbons (PAHs) in Street Dust from the Tokyo Metropolitan Area, Sci. Total. Environ., 107, 45-69, 1991.

Tang, D. L., Satyanarayana, B., Zhao, H., and Singh, R. P.: A preliminary analysis of the Sumatran tsunami influence on Indian Ocean CHL-a and SST, Adv. Geosci., 5, 15-20, 2006, http://www.adv-geosci.net/5/15/2006/.

Tobiszewski, M. and Namieśnik, J.: PAH diagnostic ratios for the identification of pollution emission sources, Environ. Pollut., $162,110-119,2012$.

Tolosa, I., de Mora, S., Sheikholeslami, M. R., Villeneuve, J., Bartocci, J., and Cattini, C.: Aliphatic and aromatic hydrocarbons in coastal Caspian Sea sediments, Mar. Pollut. Bull., 48, 44-60, 2004

Tolosa, I., Mesa-Albernas, M., and Alonso- Hernández, C. M.: Inputs and sources of hydrocarbons in sediments from Cienfuegos bay, Cuba, Mar. Pollut. Bull., 58, 1624-1634, 2009.

Tsuji, Y., Namegaya, Y., Matsumoto, H., Iwasaki, S. I., Kanbua, W., Sriwichai, M., and Meesuk, V.: The 2004 Indian tsunami in Thailand: Surveyed runup heights and tide gauge records, Earth Planets Space, 58, 223-232, 2006.
UNEP: After the Tsunami: Rapid Environmental Assessment. United Nations Environment Programme, Nairobi, 140 pp., 2005.

Wang, X., Sun, S., Ma, H., and Liu, Y.: Sources and distribution of aliphatic and polyaromatic hydrocarbons in sediments of Jiaozhou Bay, Qingdao, China, Mar. Pollut. Bull., 52, 129-138, 2006.

Wang, H. S., Cheng, Z., Liang, P., Shao, D. D., Kang, Y., Wu, S. C., Wong, C. K. C., and Wong, M. H.: Characterization of PAHs in surface sediments of aquaculture farms around the Pearl River Delta, Ecotox. Environ. Safe., 73, 900-906, 2010.

Wattayakorn, G.: Marine environmental status in the Thai waters, Coast. Mar. Sci., 29, 87-94, 2005.

Yan, W., Chi, J., Wang, Z., Huang, W., and Zhang, G.: Spatial and temporal distribution of polycyclic aromatic hydrocarbons (PAHs) in sediments from Daya Bay, South China, Environ. Pollut., 157, 1823-1830, 2009.

Yang, Y., Vanmetre, P. C., Mahler, B. J., Wilson, J. T., Ligouis, B., Razzaque, M. D. M., Schaeffer, D. J., and Werth, C. J.: Influence of coal-tar Sealcoat and other carbonaceous materials on polycyclic aromatic hydrocarbon Loading in an urban Watershed, Environ. Sci. Technol., 44, 1217-1223, 2010.

Yunker, M. B., Macdonald, R. W., Veltkamp, D. J., and Cretney, W. J.: Terrestrial and marine biomarkers in a seasonally ice-covered Arctic estuary - integration of multivariate and biomarker approaches, Mar. Chem., 49, 1-50, 1995.

Yunker, M. B., Macdonald, R. W., Vingarzan, R., Mitchell, R. H., Goyette, D., and Sylvestre, S.: PAHs in the Fraser River basin: a critical appraisal of PAH ratios as indicators of PAH source and composition, Org. Geochem., 33, 489-515, 2002.

Yunker, M. B. and Macdonald, R. W.: Petroleum biomarker sources in suspended particulate matter and sediments from the Fraser River Basin and Strait of Georgia, Canada, Org. Geochem., 34, 1525-1541, 2003.

Yunker, M. B., Macdonald, R. W., Snowdon, L. R., and Fowler, B. R.: Alkane and PAH biomarkers as tracers of terrigenous organic carbon in Arctic Ocean sediments, Org. Geochem., 42, 1109_ 1146, 2011.

Zakaria, M.P., Takada, H., Ohno, K., Yamada, J., Kouno, E., and Kumata, H.: Distribution of Polycyclic Aromatic Hydrocarbons (PAHs) in Rivers and Estuaries in Malaysia: A Widespread Input of Petrogenic PAHs, Environ. Sci. Technol., 36, 1907-1918, 2002.

Zhang, X. F., Tang, D.L., Li, Z.Z., and Zhang, F. P.: The effects of wind and rainfall on suspended sediment concentration related to the 2004 Indian Ocean tsunami, Mar. Pollut. Bull., 58, 13671373, 2009.

Zhou, J. L., Fileman, T. W., Evans, S., Donkin, P., Readman, J. W., Mantoura, R. F. C., and Rowland, S.: The partition of fluoranthene and pyrene between suspended particles and dissolved phase in the Humber Estuary: a study of the controlling factors, Sci. Total. Environ., 244, 305-321, 1999. 